\title{
Genetic architecture of body size in mammals
}

\author{
Kathryn E Kemper ${ }^{1 *}$, Peter M Visscher ${ }^{2,3}$ and Michael E Goddard ${ }^{1,4}$
}

\begin{abstract}
Much of the heritability for human stature is caused by mutations of small-to-medium effect. This is because detrimental pleiotropy restricts large-effect mutations to very low frequencies.
\end{abstract}

Keywords Human height, mutation effects, mutationselection balance.

Body size, as measured by height in humans or weight in domestic species, is an archetypical quantitative or complex trait that shows continuous variation. It has been extensively recorded and studied for over a century because of its importance to ecology, its relevance in farming, and because it is an important indicator of human growth and health [1]. The genetic architecture underlying body size was initially uncertain and Fisher proposed an infinitesimal model that was successfully applied for many years [2]. This model, with an infinite number of loci, each with infinitesimal effect, is not literally true but it does provide a good fit to the data. In more recent times the infinitesimal model has gradually been replaced by a finite number of loci, each with discrete mutations. However, observations now form almost two disjointed sets: one set in which individual mutations have large effects (that is, so-called Mendelian traits) and another set where variants have small effects. This review attempts to bridge the gap between these two sets of observations using body size as an example of an extensively studied complex trait in mammalian species.

The genetic architecture underlying variation in complex traits is currently a topic of extensive debate. This is particularly true for human complex diseases but also for agriculture because of its impact in predicting future phenotypes (for example, [3-6]). Primarily it is the number, size and frequency of mutations that are under the most scrutiny. Taking the human disease example,

*Correspondence: kathryn.kemper@dpi.vic.gov.au

'Faculty of Land and Environment, University of Melbourne, Parkville, Victoria 3010, Australia

Full list of author information is available at the end of the article some argue for a common disease common variant hypothesis where genetic susceptibility to disease is the result of many relatively high-frequency mutations each with small effect on disease susceptibility. However, others argue for a rare variant common disease hypothesis where many low-frequency mutations have large effects. As we shall see, observations on the genetic architecture underlying body size for humans and other mammals provide evidence for both hypotheses. Our discussion begins by describing the number, frequency and size of mutations with large effects for humans, mice and domesticated species. We then move onto genomewide association studies (GWASs) that have investigated segregating variation in these species. We find evidence for moderate-to-large effect mutations in domestic species but highlight that this category of mutations goes undetected in human studies. Finally, we apply simple evolutionary theory to explain the observed distribution of mutation effects for human stature. Our model implies that most of the segregating variation in human height is caused by mutations with small-to-moderate effects.

\section{Variants of large effect}

\section{Family studies in humans}

Identification of causative mutations for so-called Mendelian traits has been possible by studying the segregation within families of mutations and phenotypes. Such mutations must have large effects so that individuals can be classified into genotype classes using their phenotype despite the background variation caused by other genes and environmental effects. Abnormal stature, for example, is generally diagnosed by clinicians when individuals are greater than \pm 2 standard deviation (SD) units from the population average. A recent survey of Mendelian traits causing aberrant stature and other obvious skeletal abnormalities in humans revealed the involvement of at least 241 genes [7].

Details for a sample of ten Mendelian disorders are given in Table 1. The overwhelming observation is that many conditions affect stature, and extensive details are available for even the rarest of conditions. In effect, modern healthcare systems have provided an efficient global screen for human mutations [8]. Despite the complexities, some similarities between Mendelian disorders can be observed, and these include the following: 
Table 1. Genetic properties and complexities of ten conditions reported in humans with short or tall stature phenotypes (cases represent a cross-section of rare and extremely rare disorders)

\begin{tabular}{|c|c|c|c|}
\hline Syndrome & Gene & $\begin{array}{l}\text { Stature } \\
\text { effect }^{\mathrm{a}}\end{array}$ & Inheritance ${ }^{b}$ \\
\hline $\begin{array}{l}\text { Marfan syndrome } \\
\text { (OMIM 154700) }\end{array}$ & FBN1 (fibrillin 1) & $\begin{array}{c}+2.2 \\
\mathrm{SD}\end{array}$ & $\begin{array}{l}\text { Autosomal dominant; } \\
25 \% \text { de novo mutations; } \\
\text { prevalence of } 2 \text { to } 3 \\
\text { in } 10,000 \text { live births; } \\
\text { most alleles exhibit } \\
\text { haploinsufficiency (where } \\
\text { the product from a single } \\
\text { functional copy of the gen } \\
\text { is insufficient for normal } \\
\text { function) }\end{array}$ \\
\hline $\begin{array}{l}\text { Sotos syndrome } \\
\text { (OMIM 17550) }\end{array}$ & $\begin{array}{l}\text { NSD1 (nuclear } \\
\text { receptor binding } \\
\text { SET domain protein } \\
\text { 1) }\end{array}$ & $\begin{array}{l}+2 \\
\mathrm{SD}\end{array}$ & $\begin{array}{l}\text { Autosomal dominant; } 95 \% \\
\text { de novo mutations; } 1 \text { in } \\
14,000 \text { live births }\end{array}$ \\
\hline $\begin{array}{l}\text { Beals syndrome } \\
\text { (OMIM 121050) }\end{array}$ & FBN2 (fibrillin 2) & $\begin{array}{l}+2 \\
\mathrm{SD}\end{array}$ & $\begin{array}{l}\text { Autosomal dominant; rare; } \\
\text { mostly inherited }\end{array}$ \\
\hline
\end{tabular}

(OMIM 121050)

\section{$3 \mathrm{M}$ syndrome}

(OMIM 273750)

CUL7 (cullin 7)

Costello

syndrome (OMIM

218040)

HRAS (v-Ha-ras

Harvey rat sarcoma

viral oncogene

homolog)

Achondroplasia

(OMIM 100800)
-5.6 Autosomal recessive;

SD very rare, 40 to 50 cases reported

-5 Autosomal dominant; SD mostly de novo mutations: very rare, 250 cases worldwide
FGFR3 (fibroblast growth factor receptor 3)
Cornelia de Lange NIPBL (nipped-B syndrome (OMIM homolog)

122470) (Drosophila)
Autosomal dominant; 80\% de novo mutations; 0.5 to 1.5 in 10,000 live births

\section{Hetero-}

geneity

$>500$

mutations

FBN1 is a very large (>600 kb) and highly

fragmented (65 exons) gene; phenotypic

heterogeneity and a spectrum of Marfan-like

disorders suggest involvement of other

genes; mutations in the functionally related

transforming growth factor- $\beta$ receptor,

type II gene (TGFBR2) is also known to

cause Marfan syndrome; symptoms include disproportionate overgrowth of limbs, and ocular and cardiovascular abnormalities

$>100 \quad$ NSD1 mutations in $80 \%$ to $90 \%$ of cases;

mutations symptoms include characteristic facial features, overgrowth and mild-to-severe learning disabilities with possible cardiac, dental and renal abnormalities; increased tumor risk

10 Similar phenotype to Marfan syndrome mutations but with fewer complications; FBN2 abnormalities in $27 \%$ to $70 \%$ of cases: probable involvement of other loci; reports of a lethal mutation and somatic/germline mosaicism

$>45 \quad$ Mutations in OBSL 1 and CCDC8 can also mutations cause $3 \mathrm{M}$ syndrome; symptoms include severe prenatal and postnatal growth retardation, characteristic facial features and normal intelligence

$>10$ Recurrent missense mutation in HRAS mutations reported in up to $80 \%$ of cases; somatic/ germline mosaicism confirmed in one case and suspected in others; symptoms include postnatal failure to thrive, intellectual disability, coarse facial features, cardiac abnormalities and an increased risk of malignant tumors

$>10$ Most common form of dwarfism; $97 \%$ of mutations cases show one of two mutations that cause a missense glycine to arginine substitution at position 380 in FGFR3; missense mutation associated with gain-of-function and overactivation of negative growth control; evidence for increasing prevalence with increasing paternal age; other mutations in FGFR3 implicated in other diseases (including more severe skeletal dysplasias); symptoms include shortened limbs and facial features; unexplainably high prevalence and de novo mutations suggest other factors (such as positive selection of sperm) may influence the prevalence of the disease

$>80 \quad$ NIPBL abnormalities reported in $60 \%$ of mutations cases; mutations of SMC1A (X-linked) and SMC3 in $<6 \%$ of cases; maybe involvement of other loci; germline mosaicism implicated; phenotypic heterogeneity, including characteristic facial features, postnatal growth retardation, hirsutism and possible oligodactyly (missing digits); symptoms may approach non-syndromic mental retardation
References

$[10,37-47]$

1 in 10,000 to 1 in 30,000

live births 
Table 1. Continued

\begin{tabular}{|c|c|c|c|c|c|c|}
\hline Syndrome & Gene & $\begin{array}{l}\text { Stature } \\
\text { effect }^{\mathrm{a}}\end{array}$ & Inheritance ${ }^{b}$ & $\begin{array}{l}\text { Hetero- } \\
\text { geneity }\end{array}$ & Notes & References \\
\hline $\begin{array}{l}\text { Growth hormone } \\
\text { insensitivity } \\
\text { syndrome (GHIS) } \\
\text { (OMIM 262500) }\end{array}$ & $\begin{array}{l}\text { GHR (growth } \\
\text { hormone receptor) }\end{array}$ & $\begin{array}{l}-7 \text { to } \\
-3.6 \\
\text { SD }\end{array}$ & $\begin{array}{l}\text { Mostly autosomal recessive; } \\
\text { rare, } 100 \text { to } 200 \text { cases } \\
\text { reported worldwide mostly } \\
\text { in two large cohorts }\end{array}$ & $\begin{array}{l}\quad>50 \\
\text { mutations }\end{array}$ & $\begin{array}{l}\text { Biochemical and clinical heterogeneity; } \\
\text { most severe form (Laron syndrome, effect -7 } \\
\text { SD) to partial growth hormone insensitivity } \\
\text { (-3.6 SD); one case of autosomal dominant } \\
\text { inheritance; probable involvement of } \\
\text { other loci as no abnormalities in GHR } \\
\text { detected in some patients; symptoms may } \\
\text { include severe postnatal growth failure, } \\
\text { underdeveloped facial bones and slow } \\
\text { motor development }\end{array}$ & [78-81] \\
\hline $\begin{array}{l}\text { Geleophysic } \\
\text { dysplasia (OMIM } \\
231050)\end{array}$ & $\begin{array}{l}\text { ADAMTSL2 } \\
\text { (ADAMTS-like 2) }\end{array}$ & $\begin{array}{l}-4.5 \\
S D\end{array}$ & $\begin{array}{l}\text { Autosomal recessive; very } \\
\text { rare, } 31 \text { reported cases }\end{array}$ & $\begin{array}{l}>5 \\
\text { mutations }\end{array}$ & $\begin{array}{l}\text { Very similar to Weill-Marchesani syndrome } \\
\text { and acromicric dysplasia; missense and } \\
\text { nonsense mutations detected in } 70 \% \text { of } \\
\text { individuals; possible involvement of other } \\
\text { genes; high early childhood mortality } \\
\text { (33\%) resulting from cardiac and respiratory } \\
\text { dysfunctions }\end{array}$ & {$[82,83]$} \\
\hline $\begin{array}{l}\text { Hypochrondro- } \\
\text { plasia (OMIM } \\
146000)\end{array}$ & $\begin{array}{l}\text { FGFR3 (fibroblast } \\
\text { growth factor } \\
\text { receptor } 3 \text { ) }\end{array}$ & $\begin{array}{l}-3.2 \\
S D\end{array}$ & $\begin{array}{l}\text { Autosomal dominant; } \\
\text { assumed mostly de novo } \\
\text { mutations with prevalence } \\
\text { similar to achondroplasia } \\
\text { (that is, } 1 \text { in } 15,000 \text { to } 1 \text { in } \\
40,000 \text { births) }\end{array}$ & $\begin{array}{l}>10 \\
\text { mutations }\end{array}$ & $\begin{array}{l}\text { Sever hypochondroplasia is similar to mild } \\
\text { achondroplasia; most hypochondroplasia } \\
\text { cases are associated with alanine-for- } \\
\text { asparagine substitution in exon } 10 \text { of FGFR3; } \\
\text { other mutations account for }<2 \% \text { of cases; } \\
\text { suspected involvement of other loci for } \\
\text { milder forms of the disorder }\end{array}$ & [84-86] \\
\hline
\end{tabular}

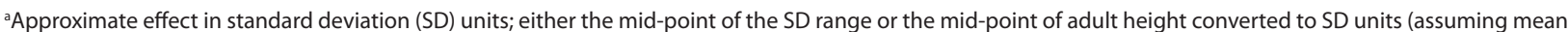
height $174 \mathrm{~cm}$ and SD $7 \mathrm{~cm}$, Australian Bureau of Statistics [61]); when there was no attempt to quantify 'short' or 'tall' stature effect size is assumed to be \pm 2 SD; 'bfor cases reported as rare, the assumed frequency rate is 1/100,000 births. kb, kilobase; OMIM, Online Mendelian Inheritance in Man [87].

(1) Most mutations confer a range of clinical symptoms caused by pleiotropic effects of the mutation. For instance, Cornelia de Lange syndrome can cause growth failure and profound intellectual disability [9]. Pleiotropy is also a common feature for a range of other human diseases [10]. (2) The syndromes have a very low prevalence and de novo mutations often account for a substantial portion of this incidence. (3) Most of the conditions show extensive allelic heterogeneity. For example, a prevalence (in the order) of 1 in 10,000 births and a $25 \%$ de novo mutation rate for Marfan syndrome (Table 1) suggests, assuming a mutation rate per base of $10^{-8}$ per generation, that there may be up to 2,500 possible mutable positions in genes causing Marfan-like phenotypes (that is, $0.25 \times 1 \times 10^{-4} / 1 \times 10^{-8}=2,500$ mutable positions, equivalent to approximately $1 \%$ of bases in FBN1). (4) Different mutations within a particular gene may be associated with different (related) clinical diseases or different degrees of severity for a single disease. For example, the type of missense mutation in the lysine codon at position 650 (Lys650) in FGFR3 determines the relatively mild hypocondroplasia (Lys650Asn/Gln) or the more severe conditions of SADDAN (severe achondroplasia with developmental delay and acanthosis nigricans) or thanatophoric dysplasias (Lys650Glu/Met) [11]. Similarly in Marfan syndrome, patients with a premature stop codon or mutations in exons 24 to 32 of FBN1 have more severe symptoms than those with inframe mutations or mutations at different locations [12]. Potentially more disruptive mutations and those in highly conserved regions lead to increased clinical severity of the phenotype [13]. (5) Both dominant and recessive mutations affect stature and these do not correlate perfectly with gain or loss of function for the gene. (6) Known mutations often cannot account for all cases of a particular disease. Usually other genes, presumably with a functional relationship to the known loci, are thought to be involved. (7) There are more mutations causing a reduction in height than those causing an increase.

\section{Mutations in laboratory mice with large effects}

Spontaneous and chemically induced mutations affecting size have been reported in mice. As with family studies in humans, the effect of the mutation needs to be large (>3 SD) to be recognized, and the causative gene identified and reported [14]. These approaches probably miss loci where the mutations have more subtle effects [15]. Despite this, spontaneous and chemically induced screens have been successful in identifying over 500 genes associated with abnormal postnatal growth or body size [16]. By comparison, this is more than twice the number of loci identified in humans.

Allelic heterogeneity is not a feature of the mouse mutations as it is in humans, because relatively few alleles 
are sampled in the small numbers of inbred lines typically used. Similarly, the identification methods also bias the observed inheritance patterns for mutations. Thus, many of the spontaneous mutations initially identified, such as little, pygmy or Ames dwarf, are recessive [16,17], whereas the chemically induced mutagenesis screens tend to identify dominant, rather than recessive, alleles [14]. These idiosyncrasies relate to identification methods, because of inbreeding strategies or the efficiencies for detecting dominant phenotypes, rather than biological characteristics.

\section{Gene knockout in mice}

The direct manipulation of the mouse genome via gene knockout technology implicates genes in growth and development by inducing a loss-of-function mutation at specific loci. This is advantageous because both viable and non-viable mutations are represented, but limited because genes must be specifically targeted for knockout candidates. Surveying only viable mutants, Reed et al. [18] extrapolate from reported knockout lines to estimate approximately 6,000 genes may cause either 'lighter and smaller' or 'larger and heavier' body size in mice (that is, $25 \%$ of the estimated total number of genes in mammalian genomes [19]). Reed et al. did not attempt to define the size of effect for each locus [18], but presumably effects were large because they were readily noticeable. The estimate of 6,000 genes may also be an underestimate of the number of loci influencing body size because of the lethality for some knockouts of genes known to affect body size in other mammals (for example, FGF4; Table 2). Reed et al. observed that nullifying genes caused about ten times as many small body size phenotypes compared with large body size phenotypes, similar to natural mutations in humans [18]. These observations support the hypothesis that the genome is biased towards a larger rather than smaller body size $[18,20]$.

\section{Mutations of large effect in domestic species}

Only a handful of causative mutations affecting body size in domestic livestock and companion species have been identified (Table 2). Six of the seven genes also have mutations with large effect for body size in mice and/or humans. Most of the mutations have been identified within a single breed, such as the FGFR3 mutation causing limb overgrowth in Suffolk sheep [21], and these mutations tend to be recessive deleterious mutations. This bias toward identification of recessive conditions can be explained by the relatively small effective population size of many domestic species. Thus, a recessive deleterious mutation may drift to high frequency within a breed before a problem is recognized (for example, [22]). In contrast, an animal with a deleterious, dominant mutation will be immediately culled and the causal gene is unlikely to be investigated. For recessive mutations, once the syndrome is recognized an effort is made to discover the cause.

An alternative to the within-breed approach is to examine differences across breeds. This approach aims to identify breed-defining loci under the assumption that selective sweeps will be evident in the genome. Examples of mutations identified using across breed identification methods include the FGF4 mutation for disproportionate short stature in dogs such as the dachshund (Table 2) and, although the causative mutations are unknown, the IGF1 mutation in small dog breeds, and the PLAG1CHCHD7 intergenic region in Holstein-Friesian and Jersey cattle [23-25]. Common haplotypes for these mutant alleles suggest strong selection and identical mutations by descent, rather than selection for recurring new (de novo) mutations. For example, at least one copy of the haplotype carrying the mutant allele FGF4 mutation is found in 19 different dog breeds with chondrodysplasia [24]. Similarly for IGF1, the small IGF1 haplotype was homozygous in 23 different small dog breeds [23]. One problem created by these selective sweeps it that causative mutations are often difficult to isolate. Only analysis of different breeds or outbred populations, preferably where the mutation is not under selection, will enable the identification of the mutation by breaking up the observed linkage disequilibrium (LD) blocks. As observed in mice, the relative allelic and locus homogeneity found for dogs and livestock contrasts with the diversity observed for mutations conferring obvious phenotypes in humans (as listed in Table 1).

Results from livestock and companion species highlight that mutations with large-to-moderate effects are present without severe pleiotropic effects and can reach high frequencies in artificially selected populations. The PLAG1-CHCHD7 intergenic region, for example, was identified by Karim et al. [25] because alternative alleles were at high frequency in the Holstein-Friesian and Jersey breeds. The effect of the region is moderate, with homozygotes approximately $\pm 0.4 \mathrm{SD}$ from the heterozygote genotypes (assuming the SD of body weight in cattle is about $50 \mathrm{~kg}$ ). Similarly in dogs, the genetic architecture is such that $\leq 3$ loci can explain much of the between-breed phenotypic variation for body weight [26]. This implies the presence of high frequency alleles with large-to-moderate effects on body size within a breed.

\section{Variants with small effects}

\section{Studies in humans}

GWASs for stature in humans provide one of the best resources for studying the segregating genetic variation in body size. Over 20 GWASs for human height have 
Table 2. Genes with known mutations ${ }^{\mathrm{a}}$ affecting body size identified from domestic species, and corresponding conditions in humans and/or mice

\begin{tabular}{|c|c|c|c|c|c|}
\hline Species & Syndrome & Gene & Phenotype description & Conditions in humans and/or mice & References \\
\hline Bos taurus & $\begin{array}{l}\text { Disproportionate } \\
\text { chondrodysplasia } \\
\text { in Japanese Brown } \\
\text { cattle }\end{array}$ & $\begin{array}{l}\text { EVC2 (Ellis-van Creveld } \\
\text { syndrome 2) }\end{array}$ & $\begin{array}{l}\text { SNP and deletion variant; } \\
\text { recessive mutation }\end{array}$ & $\begin{array}{l}\text { Humans: skeletal dysplasia, Ellis-van } \\
\text { Creveld syndrome (OMIM 225500); } \\
\text { autosomal recessive }\end{array}$ & {$[88,89]$} \\
\hline Bos taurus & $\begin{array}{l}\text { Disproportionate } \\
\text { chondrodysplasia in } \\
\text { Angus cattle }\end{array}$ & $\begin{array}{l}\text { PRKG2 (protein kinase, } \\
\text { cGMP-dependent, } \\
\text { type II) }\end{array}$ & $\begin{array}{l}\text { SNP variant; recessive } \\
\text { homozygotes are } 15.8 \\
\text { cm shorter at birth than } \\
\text { wild-type; suggestion of } \\
\text { embryonic lethality }\end{array}$ & $\begin{array}{l}\text { Mice: homozygous null mice exhibit } \\
\text { disproportionate dwarfism, and } \\
\text { decreased weight and body length }\end{array}$ & {$[90,91]$} \\
\hline Bos taurus & $\begin{array}{l}\text { Dwarfism in Dexter } \\
\text { cattle }\end{array}$ & ACAN (aggrecan) & $\begin{array}{l}\text { Insertion variant; recessive } \\
\text { lethal; heterozygotes } \\
\text { show disproportionate } \\
\text { chondrodysplasia }\end{array}$ & $\begin{array}{l}\text { Humans: short stature and skeletal } \\
\text { dysplasia (for example, OMIM 165800); } \\
\text { dominant and recessive forms. Mice: } \\
\text { spontaneous mutation results in } \\
\text { dwarfism and skeletal abnormalities; } \\
\text { recessive lethal }\end{array}$ & {$[92-94]$} \\
\hline Bos indicus & $\begin{array}{l}\text { Dwarfism in } \\
\text { Brahman cattle }\end{array}$ & $\begin{array}{l}\text { GH1 (growth } \\
\text { hormone 1) }\end{array}$ & $\begin{array}{l}\text { SNP variant; recessive } \\
\text { homozygotes are } 70 \% \text { of } \\
\text { wild-type phenotype height } \\
\text { and weight }\end{array}$ & $\begin{array}{l}\text { Humans: proportionate short stature } \\
\text { (for example, OMIM 173100); dominant } \\
\text { and recessive forms. Mice: ENU-induced } \\
\text { mutation with additive effects causing } \\
\text { dwarfism }\end{array}$ & {$[95-97]$} \\
\hline $\begin{array}{l}\text { Canis lupus } \\
\text { familiaris }\end{array}$ & $\begin{array}{l}\text { Disproportionate } \\
\text { chondrodysplasia } \\
\text { in dogs }\end{array}$ & $\begin{array}{l}\text { FGF4 (fibroblast } \\
\text { growth factor } 4 \text { ) }\end{array}$ & $\begin{array}{l}\text { SNP variant; identified by } \\
\text { between-breed analyses; } \\
\text { shortened limbs }\end{array}$ & $\begin{array}{l}\text { Humans: involved in cancer and limb } \\
\text { development. Mice: null homozygous } \\
\text { mice show embryonic mortality; mice } \\
\text { with conditional mutations show } \\
\text { normal limb development }\end{array}$ & {$[24,98-100]$} \\
\hline $\begin{array}{l}\text { Sus scrofa } \\
\text { domesticus }\end{array}$ & $\begin{array}{l}\text { Disproportionate } \\
\text { chondrodysplasia in } \\
\text { Danish Landrace }\end{array}$ & $\begin{array}{l}\text { COL10A1 (collagen, } \\
\text { type X, alpha 1) }\end{array}$ & $\begin{array}{l}\text { SNP variant; dominant } \\
\text { mutation; shortened limbs }\end{array}$ & $\begin{array}{l}\text { Humans: dominant mutation causes } \\
\text { Schmid metaphyseal chondrodysplasia } \\
\text { (OMIM 156500). Mice: dominant } \\
\text { mutation shows abnormal skeletal } \\
\text { growth }\end{array}$ & {$[101-105]$} \\
\hline Ovis aries & $\begin{array}{l}\text { Disproportionate } \\
\text { chondrodysplasia in } \\
\text { Suffolk sheep }\end{array}$ & $\begin{array}{l}\text { FGFR3 (fibroblast } \\
\text { growth factor } \\
\text { receptor 3) }\end{array}$ & $\begin{array}{l}\text { SNP variant; overgrowth } \\
\text { of limbs; semi-lethal in } \\
\text { homozygotes; cannon } \\
\text { bone length }+1 \mathrm{~cm} \text { in } \\
\text { heterozygotes; recessive } \\
\text { but speculated co- } \\
\text { dominance }\end{array}$ & $\begin{array}{l}\text { Humans: associated with } 13 \\
\text { phenotypes, including dwarfing } \\
\text { syndromes and cancer (for example, } \\
\text { OMIM 100800). Mice: homozygous } \\
\text { null mice show abnormal skeletal } \\
\text { development, decreased growth and } \\
\text { premature death; mild symptoms in } \\
\text { heterozygotes }\end{array}$ & {$[21,87]$} \\
\hline
\end{tabular}

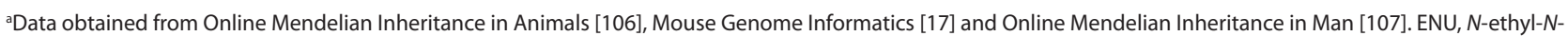
nitrosourea.

been published and 389 genes have been associated with height $\left(P<1 \times 10^{-5}\right.$; Table S1 in Additional file 1$)$. In contrast to the mutations with large effect, causative mutations underlying significant associations have seldom been identified. The assumption is that significant SNP markers are in high LD with a causal mutation in a nearby gene. Sometimes there are difficulties in distinguishing between two genes near to a single marker and, occasionally, no known genes are located in the region. However, associations between SNP and height are highly significant, replicate in independent samples of people and, in some cases, in different racial groups (Table S2 in Additional file 1) [27]. The genes near significant SNPs are not a random sample of genes because they are enriched for genes implicated in skeletal development and often they are in high LD with nonsynonymous coding mutations or known regulatory mutations [7].

The estimated effects from human height GWASs are very small (0.02 to $0.13 \mathrm{SD})$, usually additive rather than recessive or dominant, and have moderate minor allele frequency ( 0.01 to 0.5$)$. The effect of the causal mutation could be larger than the estimated effect of the SNP and its minor allele frequency (MAF) lower, but the most parsimonious explanation is that the effect sizes and MAF for mutations are similar to those of the associated SNP. This implies that the mutations currently detected by GWASs are relatively common and the effect size for 
these mutations is small. However, the SNPs identified by GWASs explain only a small proportion (approximately $12 \%$ ) of the known inherited variation for stature [7]. This has caused much debate among geneticists (Box 1 ). If the 180 loci identified by Lango Allen et al. [7] explain 12\% of the genetic variation, then this implies a minimum of 1,500 loci to explain the segregating genetic variance for stature in human populations (that is, $180 / 0.12=1,500$ ). This number is the minimum expected because loci identified by Lango Allen $e t$ al. are presumably a subset of loci with the largest influence on the genetic variance.

The genes implicated in the GWASs are sometimes the same genes identified with large effect mutations for height (Table 3) [7]. Therefore, genes may have mutations causing both large and small effects on stature [27], highlighting that there may be multiple alleles at a locus. Multiple alleles have the effect of reducing power to detect loci through GWASs. This is because each mutation is likely to be in LD with a different nearby SNP and the frequency of mutations is likely to reduce as number of segregating alleles increases. Allelic heterogeneity may explain why some of the genes with large effect mutations for height (for example, FBN1, as listed in Table 1) are not identified by GWASs. Allelic heterogeneity is not an important factor for detection in family-based studies because mutations are identical-by-descent within a family.

\section{Studies in non-human mammals}

Generally, GWASs in domestic species explain a much higher percentage of the genetic variance than human GWASs [28]. In mice, for example, the study by Valdar et al. [29] explains an average of $75 \%$ of the genetic variance in 97 traits, including body weight. GWASs in mice are not performed with a wild population but with a heterogeneous population derived from inbred strains. These heterogeneous strains show LD over long genomic distances and this probably explains why a higher proportion of variance is captured. In addition, Valdar et al. assign an identical-by-decent probability to each marker [29]. This may track the causal polymorphisms from each strain better than the use of individual SNPs because, for example, Valdar et al. [29] also show that diallelic markers (that is, SNPs) cannot account for the described loci in a third of cases.

A further consequence of LD over long distances is that positioning the causal polymorphism can be very difficult from GWASs in model species. This is similar to the problem encountered for breed-defining loci in dogs, for example; however, loci identified from GWASs are segregating variants causing within-population variation in body size. In the study of Valdar et al. [29], quantitative trait loci regions for body weight contain up to 22 genes within the $50 \%$ confidence interval. It is likely that some

\section{Box 1. The case of the missing heritability}

The inability of genome-wide association studies (GWASs) to explain most of the known inherited variation in complex traits (including human height) has caused much debate (for example, [33]). For instance, Lango Allen et al. [7] used $>100,000$ people to find 180 SNPs significantly associated with height. When the effects of these SNPs were estimated in an independent sample, they explained only $10 \%$ of the phenotypic variance although the heritability of height is approximately $80 \%$. So why do we not detect these missing variants? Part of the reason for the difference between $80 \%$ and $10 \%$ is that the experiment lacked power to find SNPs with small effects despite the large sample size [27]. Lango Allen et al. [7] estimate the power to find associations of the size they discovered ( 0.02 to 0.13 standard deviation (SD) units) and suggest that there would be 700 loci with effect sizes in this range that would collectively explain 16\% of the phenotypic variance. In contrast, Yang et al. [34] estimate that $45 \%$ of the phenotypic variance could be explained by all the SNPs together when the significance level of individual markers is ignored. The difference between $16 \%$ and $45 \%$ is because SNPs with real associations with height had an effect that was too small to be detected by Lango Allen et al. This group of SNPs could include two classes of mutations, one with very small effects $(<0.02 \mathrm{SD})$ and another with small ( 0.02 to $0.13 \mathrm{SD}$ ) or intermediate (0.1 to $1 \mathrm{SD}$ ) effects but in low linkage disequilibrium (LD) with many SNPs. Under these conditions, the analysis of Lango Allen et al. may underestimate the number of mutations with small effects, because if mutations are associated with several SNPs the effect of any one SNP may be too small to be significant in a GWAS. However, the collective variance explained by all associated SNPs is included in the analysis of Yang et al. [34]. The difference between $45 \%$ and $80 \%$ is likely to be caused by imperfect LD between the SNP and the causal mutations. That is, even when multiple SNPs track a mutation they may not completely explain variance at the loci. This lack of perfect LD could be due to the causal polymorphisms having a low frequency (for example, a minor allele frequency $<0.1$ ). We suggest that some of these loci could be the missing intermediate effect mutations highlighted by Figure 2 .

of these regions contain multiple causal polymorphisms, particularly for regions that show differences between the identical-by-descent and diallelic results.

Association studies in livestock generally have small sample sizes (approximately 2,000 records), and hence relatively high false discovery rates compared with GWASs in humans (for example, [30]). This means that defining genes identified by livestock GWASs is more uncertain than those identified in humans. However, Pryce et al. [31] tested 55 genes that had previously been identified in human GWASs for affects on stature in dairy and beef cattle [31]. A total of eight genomic regions with ten genes (Table 2; Table $S 2$ in Additional file 1) showed significant associations $\left(P<1 \times 10^{-3}\right)$. This confirms that real causal mutations are being detected by human GWASs, and highlights that mutations in the same genes 
Table 3. Genes identified with both large and small-effect mutations that affect stature and skeletal formation in humans

\begin{tabular}{|c|c|c|c|c|}
\hline \multirow[b]{2}{*}{ Gene } & \multicolumn{2}{|r|}{$\begin{array}{l}\text { OMIM phenotypes } \\
\text { associated with the gene }\end{array}$} & \multicolumn{2}{|c|}{$\begin{array}{l}\text { GWASs identifying } \\
\text { the gene }\end{array}$} \\
\hline & Number & Example stature phenotype $^{a}$ & Number & Reference(s) \\
\hline ACAN (aggrecan) & 3 & $\begin{array}{l}\text { Spondyloepimetaphyseal dysplasia, aggrecan type (-) } \\
\text { (OMIM 612813) }\end{array}$ & 4 & {$[7,108-110]$} \\
\hline $\begin{array}{l}\text { ADAMTS10 (ADAM metallopeptidase with } \\
\text { thrombospondin type } 1 \text { motif, 10) }\end{array}$ & 1 & Weill-Marchesani syndrome 1, recessive (-) (OMIM 277600) & 2 & {$[109,111]$} \\
\hline ARSE (arylsulfatase E) (chondrodysplasia punctata 1) & 1 & Chondrodysplasia punctata, X-linked recessive (-) (OMIM 302950) & 2 & {$[110,112]$} \\
\hline BBS1 (Bardet-Biedl syndrome 1) & 1 & Bardet-Biedl syndrome 1 (-) (OMIM 209900) & 1 & [109] \\
\hline BBS7 (Bardet-Biedl syndrome 7) & 1 & Bardet-Biedl syndrome 7 (-) (OMIM 209900) & 1 & {$[109]$} \\
\hline$B R C A 2$ (breast cancer 2 , early onset) & 9 & Fanconi anemia, complementation group D1 (-) (OMIM 605724) & 1 & [7] \\
\hline COL11A1 (collagen, type XI, alpha 1) & 4 & Fibrochondrogenesis (-) (OMIM 228520) & 1 & [113] \\
\hline $\begin{array}{l}\text { CYP19A1 (cytochrome P450, family 19, subfamily A, } \\
\text { polypeptide 1) }\end{array}$ & 2 & Aromatase deficiency (-) (OMIM 613546) & 3 & {$[7,109,114]$} \\
\hline DYM (dymeclin) & 2 & Smith-McCort dysplasia (-) (OMIM 607326) & 4 & $\begin{array}{c}{[7,108} \\
109,112]\end{array}$ \\
\hline $\begin{array}{l}\text { EIF2AK3 (eukaryotic translation initiation factor } \\
\text { 20alpha kinase 3) }\end{array}$ & 1 & Wolcott-Rallison syndrome (-) (OMIM 226980) & 2 & {$[7,109]$} \\
\hline EXT1 (exostosin 1) & 2 & Exostoses, multiple, type 1 (-) (OMIM 133700) & 1 & [115] \\
\hline FANCC (Fanconi anemia, complementation group C) & 1 & Franconi anemia, complementation group C (-) (OMIM 227645) & 1 & [7] \\
\hline FANCE (Fanconi anemia, complementation group E) & 1 & Franconi anemia, complementation group E (-) (OMIM 600901) & 1 & [7] \\
\hline FBN2 (fibrillin 2) & 1 & Contractural arachnodactyly, congenital (+) (OMIM 121050) & 1 & [110] \\
\hline FGFR3 (fibroblast growth factor receptor 2) & 13 & Achondroplasia (-) (Table 1) & 1 & [7] \\
\hline FLNB (fibamin B, beta) & 5 & Larsen syndrome (-) (OMIM 150250) & 1 & {$[116]$} \\
\hline GALNS (galactosamine (N-acetyl)-6-sulfate sulfatase) & 1 & Mucopolysaccharidosis IVA (-) (OMIM 253000) & 1 & [7] \\
\hline GDF5 (growth differentiation factor 5) & 8 & Acromesomelic dysplasia, Hunter-Thompson type (-) (OMIM 201250) & )) 1 & [7] \\
\hline GH1 (growth hormone 1) & 4 & Growth hormone deficiency, isolated, type IA (-) (OMIM 262400) & 1 & [109] \\
\hline GHR (growth hormone receptor) & 4 & Laron dwarfism (-) (OMIM 262500) & 1 & [109] \\
\hline GHSR (growth hormone secretagogue receptor) & 1 & Short stature (-) (OMIM 604271) & 2 & {$[7,109]$} \\
\hline HMGA2 (high-mobility group AT-hook 2) & 1 & Leiomyoma, uterine, somatic ${ }^{b}(-)$ (OMIM 150699) & $9^{e}$ & $\begin{array}{l}{[7,10-112} \\
114,117,118]\end{array}$ \\
\hline IHH (Indian hedgehog) & 2 & Acrocapitofemoral dysplasia (-) (OMIM 607778) & 2 & {$[7,111]$} \\
\hline $\begin{array}{l}\text { KCNJ2 (potassium inwardly-rectifying channel, } \\
\text { subfamily J, member 2) }\end{array}$ & 3 & Atrial fibrillation, familial, 9 (-) (OMIM 613980) & 1 & [7] \\
\hline PTCH1 (patched 1) & 3 & Basal cell nevus syndrome ${ }^{(-)}$(OMIM 109400) & $3^{e}$ & $\begin{array}{c}{[7,108-109,} \\
119,120]\end{array}$ \\
\hline RNF135 (ring finger protein 135) & 1 & $\begin{array}{l}\text { Macrocephaly, macrosomia, facial dysmorphism syndrome }(+) \\
\text { (OMIM 614192) }\end{array}$ & 1 & [7] \\
\hline RPL5 (ribosomal protein L5) & 1 & Diamond-Blackfan anemia 6 $6^{d}(-)$ (OMIM 612561) & 1 & [7] \\
\hline RUNX2 (runt-related transcription factor 2) & 2 & Cleidocranial dysplasia (-) (OMIM 119600) & 1 & [7] \\
\hline $\begin{array}{l}\text { SLC39A13 (solute carrier family } 39 \text { (zinc transporter), } \\
\text { member 13) }\end{array}$ & 1 & $\begin{array}{l}\text { Spondylocheirodysplasia, Ehlers-Danlos syndrome-like (-) } \\
\text { (OMIM 612350) }\end{array}$ & 1 & [7] \\
\hline TBX15 (T-box 15) & 1 & Cousin syndrome (-) (OMIM 260660) & 2 & {$[108,121]$} \\
\hline
\end{tabular}

Genes with mutation of large effect are from the 241 genes identified by Lango Allen et al. [7] from the Online Mendelian Inheritance in Man database. Surveyed genome-wide association studies are listed in Table S1 in Additional file 1.

aThe effect of the mutation on stature phenotypes indicate reduced (-) or increased (+) height for carriers of the mutation; ${ }^{\mathrm{b} m u t a t i o n}$ identified for uterine leiomyomata associated with $1.5 \mathrm{~cm}$ decrease in height (that is, 0.21 standard deviation (SD) units, assuming SD for height is $7 \mathrm{~cm}$ ) [121, 122]; cheterogeneous condition causing skeletal abnormalities and predisposition to tumors, and there is one report of PTCH1 duplication causing microcephaly [120]; 'Diamond-Blackfan anemia is a genetically heterogeneous condition causing growth failure and RPL5 is associated with the disease; ${ }^{e}$ validated gene in cattle [31]. 
contribute to segregating variation for both human and cattle populations. This implies that mutations in these genes may occur without obvious pleiotropic effects.

Finally, divergent selection experiments in domestic species support a model of many loci affecting body size. For example, selection experiments over many generations in cattle and mice have produced phenotypes that are outside the normal range of the base population (Figure 1). MacArthur [32] shows a difference of 10.9 SD between small and large body size mice after 21 generations of selection. The selection response implies at least dozens of genes affecting the trait, but it is impossible to distinguish between dozens and thousands of loci. If we assume the same effect size as the largest effects in human GWASs (that is $<0.1 \mathrm{SD}$ ), this response would require at least 54 genes to explain the divergence of the lines (that is, $10.9 /(2 \times 0.1)=54$ genes $)$.

\section{Where are the intermediate effects?}

The allele frequencies and mutation effect for the combined results from GWASs for human height and within family studies are shown in Figure 2. This highlights the disjointed nature of the datasets. At one extreme, rare variants with large effects $(>2 \mathrm{SD})$ have been mapped using within-family segregation of markers and phenotypes. At the other extreme, there are mutations segregating at intermediate frequencies within populations that have been identified by GWASs (0.02 to $0.13 \mathrm{SD}$ ). But what has happened to the mutations with the intermediate effects? Studies in model organisms such as Drosophila suggest a continuous J-shaped distribution of effects on complex traits, where there are many loci of small and intermediate effects and few loci of larger effect [28]. In livestock and domestic species, loci with intermediate effects are also occasionally observed.

One explanation is that the intermediate effects are not efficiently detected in humans because of the current detection methodologies. This is because family-based studies detect only extreme phenotypes, whereas association studies usually detect only rare, large effect mutations and segregating mutations in high LD with SNPs at moderate allele frequencies. The power of GWASs to detect a mutation depends on both the variance explained by the mutation (that is, $2 p q a^{2}$, where $p$ is the allele frequency, $p+q=1$, and $a$ is the effect size) and the LD between the mutation and SNP. Therefore, mutations with intermediate effect but frequencies lower than common SNPs are unlikely to be detected because of the small variance explained by the locus and also because of weak LD with common SNPs. Loci with intermediate effects and poor LD with common SNPs may also explain some of the so-called 'missing heritability' (Box 1).

Mutations with intermediate effects might be detected as follows. (1) In populations subject to strong, recent

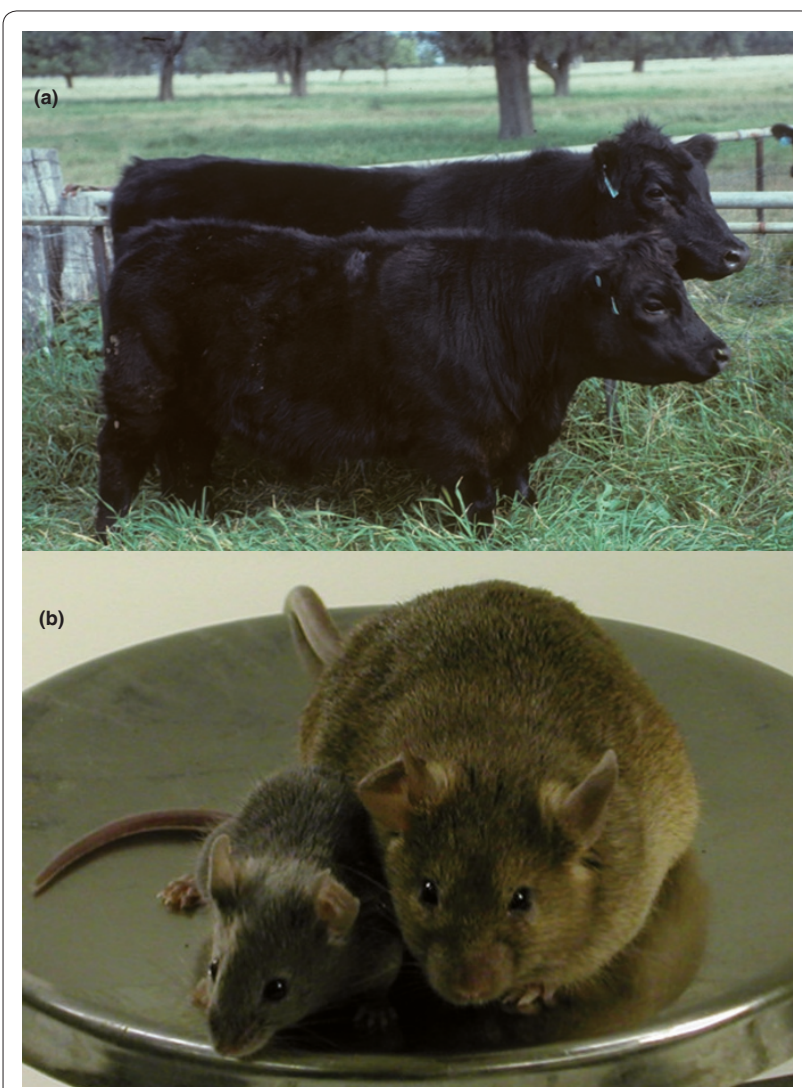

Figure 1. Selection experiments with domestic species indicate many genes underlie variation in body size. (a) Angus cattle [35] and (b) mice [36] from long-term selection experiments for high and low growth show phenotypes outside the normal range of the unselected population. The photographs were kindly supplied by Robert Herd (NSW Department of Primary Industries, NSW, Australia) and Lutz Bünger (University of Edinburgh, Edinburgh, UK). Please note that the photographs used within this figure are permitted to be used only within this publication.

artificial or natural selection, alleles that were previously rare can be driven to intermediate frequency where they are easier to detect; the PLAG1-CHCHD7 polymorphism in cattle may be an example of this. (2) Identical-bydescent haplotypes may be in complete LD with a rare mutation even though it is not in complete LD with any single SNP (for example, [29]). (3) Genomic sequence should include the causal mutations so that imperfect LD is not a problem. However, the power to detect a mutation is still determined by the variance it explains (that is, $2 p q a^{2}$ ) such that large sample sizes will still be necessary to detect variants explaining small proportions of the phenotypic variance.

\section{Understanding the observed distribution of effects for human stature}

The genetic architecture that we observe in populations today is the result of evolutionary processes. Mutation 


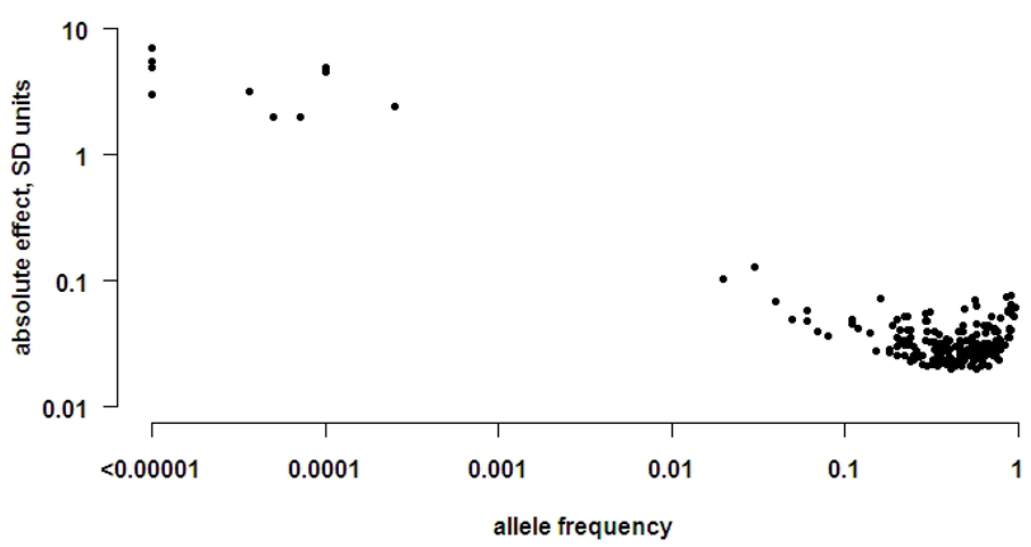

Figure 2. Mutations with intermediate effect ( 0.1 to $1 \mathrm{SD}$ units) and low frequency (0.01 to 0.001) are not detected efficiently by either linkage or genome-wide association studies. Shown are the allele effect size (x-axis) and frequency (y-axis) for GWAS results from Lango Allen et al. [7] and for the sample of mutations described in Table 1. Assumptions for frequencies and effect of mutations from Table 1 are noted in the table footer.

creates new variants and then selection and genetic drift determine the observed allele frequency. Not all mutations affect stature, but the results reviewed here suggest that there are many sites in the genome where mutation does affect size. Mutations in 241 genes are known to cause large effects on stature and skeletal features in humans. In many cases, $>20$ alleles at a gene with a large effect have been discovered and presumably not all possible sites in these genes have been discovered. Assuming there are 50 sites at 250 genes, this implies that there are 12,500 sites where mutations have a large effect (>2 SD). This is likely to be an underestimate because we previously estimated that there are 2,500 sites where mutation can cause Marfan syndrome alone.

The mutations of large effect are subject to strong selection, presumably due to their pleiotropic effects on fitness. This is shown by the high rate of de novo mutations among people carrying a mutant allele (Table 1). The selection coefficient is equal to the proportion of mutant alleles that are new mutations because an equal number of mutant alleles must be eliminated each generation. Disorders vary, but $25 \%$ de novo mutation rates are not uncommon (Table 1). Assuming a per gene mutation rate of $5 \times 10^{-7}$ (50 sites and a mutation rate of $1 \times 10^{-8}$ per site), the equilibrium allele frequency for mutations at such a locus is $5 \times 10^{-7} / 0.25=2 \times 10^{-6}$ (or a prevalence of approximately 1 in 500,000). Genes where mutations occur at much higher frequencies, such as $10^{-4}$ (or 1 in 10,000), must be due to higher mutation rates, a lower selection coefficient, genetic drift, or they may be recessive. Even at a frequency of $10^{-4}$, a mutation with effect of $2 \mathrm{SD}$ explains only $8 \times 10^{-4}$ of the phenotypic variance (for details see Additional file 1 ). However, the average frequency rate for all mutations is much less than $10^{-4}$. If we assume the average frequency is $1 \times 10^{-5}$, the variance explained per locus is $8 \times 10^{-5}$ and the total variance explained for all mutations is 0.025 of the total phenotypic variance. Considering that 0.8 of the phenotypic variance is due to inherited genetic factors, we conclude that most of the genetic variance is not due to mutations of large effect.

It seems likely that other mutations at these 250 genes can cause smaller effects on height and experimental results support this assertion [7]. Lango Allen et al. [7] discovered 180 loci for height in humans that were estimated to explain about $10 \%$ of the phenotypic variance. When they allowed for the lack of power of their experiment, they concluded there were 700 loci associated with height but these would still only explain $16 \%$ of the variance. Therefore, 700 is likely to be a considerable underestimate. As stated previously, mouse knockout experiments suggest 6,000 genes can affect height [18]. If there are 50 sites within a gene where mutation has a large effect, there are likely to be many more, including sites regulating gene expression, with small effects. If we assume 6,000 genes each with 200 sites, there are 1,200,000 mutable sites that affect height.

GWASs find SNPs with effects <0.13 SD. Even new mutations at a possible 1.2 million sites, a mutation rate of $10^{-8}$ per site and an average effect per mutation of 0.1 SD would only add $2.4 \times 10^{-4}$ to the genetic variance each generation (for details see Additional file 1). This mutation variance would need to accumulate for 3,300 generations to account for the known heritability. This implies that selection against these mutations of small effect is weak.

The selection pressure against mutations probably decreases as the size of the effect on height decreases. Mutations with very small effects may be effectively neutral in the human population and drift in allele frequency until they are lost or fixed by chance. Other mutations with intermediate effect will also drift in 
frequency but selection (due to pleiotropic effects) will cause most to have a low frequency. It is these mutations of intermediate and small effect that appear to explain most of the genetic variance. Although the mutations of intermediate effect are poorly detected by current experiments because they are not in strong LD with SNPs used in GWASs, we know they are biologically plausible because we occasionally detect such mutations in domestic animals when artificial selection or genetic drift caused by inbreeding causes their frequency to increase.

\section{Conclusions}

In summary, we have surveyed the current known mutations affecting body size in humans, mice, dogs and livestock species. Although mutations of intermediate effect are poorly detected by current experiments in humans, we know they are biologically plausible because we occasionally detect such mutations in domestic animals when artificial selection or genetic drift increases their frequency, and enables their detection. We see that genomic information is gradually building a model for genetic architecture implying many thousands of discrete genes, each with many mutable sites and (possible) segregating mutations. The frequency and size of effect for mutations differs between populations where natural selection and recent history play significant roles in determining the observed distribution. We see extensive (detrimental) pleiotropy for large-effect mutations for rare conditions in humans and also occasionally in livestock. Mutations with less obvious pleiotropy and more modest effects are observed in domestic populations because of selection and drift, but this class of mutations is rarely observed in humans. Mutations with very small effects occur at intermediate frequencies in both humans and livestock. However, the current data are limited because associations of phenotype are with genetic markers (that is, SNP) and not causal mutations.

In the future, genomic sequence data will offer the opportunity to discover the causal mutations underlying quantitative traits such as body size. Of key interest are the number, effect size and frequency of such mutations. It remains to be seen, for example, if the missing intermediate effect size mutations for human height are identified from genomic sequence and if these mutations will further explain some of the 'missing heritability'. It is likely that body size, as a model trait, will continue to inform and direct research into the future.

\section{Additional files}

Additional file 1. Genes affecting stature in mammals.

\section{Abbreviations}

GWAS, genome-wide association study; LD, linkage disequilibrium; MAF, minor allele frequency; SD, standard deviation; SNP, single nucleotide polymorphism.

\section{Competing interests}

The authors declare that they have no competing interests.

\section{Acknowledgements}

This research was supported under Australian Research Council's Discovery Projects funding scheme (project DP1093502). The views expressed herein are those of the authors and are not necessarily those of the Australian Research Council.

\section{Author details}

'Faculty of Land and Environment, University of Melbourne, Parkville, Victoria 3010, Australia. ${ }^{2}$ University of Queensland Diamantina Institute, University of Queensland, Princess Alexandra Hospital, Brisbane, Queensland 4102, Australia. ${ }^{3}$ The Queensland Brain Institute, The University of Queensland, Brisbane, Queensland 4072, Australia. ${ }^{2}$ Victorian Department of Primary Industries, AgriBiosciences Centre, LaTrobe Research and Development Park, Bundoora, Victoria 3083, Australia.

Published: 30 April 2012

\section{References}

1. Galton F: Regression towards mediocrity in hereditary stature. J Anthropol Institute 1886, 15:246-263.

2. Fisher RA: The correlation between relatives on the supposition of Mendelian inheritance. Trans R Soc Edinb 1918, 52:399-433.

3. Hayes BJ, Pryce J, Chamberlain AJ, Bowman PJ, Goddard ME: Genetic architecture of complex traits and accuracy of genomic prediction: Coat colour, milk-fat percentage, and type in Holstein cattle as contrasting model traits. PLOS Genet 2010, 6:e1001139.

4. Gibson G: Rare and common variants: twenty arguments. Nat Rev Genet 2012, 13:135-145.

5. Bodmer W, Bonilla C: Common and rare variants in multifactorial susceptibility to common diseases. Nat Genet 2008, 40:695-701.

6. Schork NJ, Murray SS, Frazer KA, Topol EJ: Common vs rare allele hypotheses for complex diseases. Curr Opin Genet Dev 2009, 19:212-219.

7. Lango Allen H, Estrada K, Lettre G, Berndt SI, Weedon MN, Rivadeneira F, Willer CJ, Jackson AU, Vedantam S, Raychaudhuri S, Ferreira T, Wood AR, Weyant RJ, Segrè AV, Speliotes EK, Wheeler E, Soranzo N, Park JH, Yang J, Gudbjartsson D, Heard-Costa NL, Randall JC, Qi L, Vernon Smith A, Mägi R, Pastinen T, Liang L, Heid IM, Luan J, Thorleifsson G, et al:: Hundreds of variants clustered in genomic loci and biological pathways affect human height. Nature 2010, 467:832-838.

8. Strachan T, Read AP: Human Molecular Genetics. 2nd edition. New York: WileyLiss; 1999.

9. Deardorff MA, Clark DM, Krantz ID: Cornelia de Lange syndrome. In: GeneReviews [Internet]. Edited by Pagon RA, Bird TD, Dolan CR, et al. Seattle: University of Washington; 2011. [http://www.ncbi.nlm.nih.gov/books/ NBK1104/]

10. Sivakumaran S, Agakov F, Theodoratou E, Prendergast JG, Zgaga L, Manolio T, Rudan I, McKeigue P, Wilson JF, Campbell H: Abundant pleiotropy in human complex diseases and traits. Am J Hum Genet 2011, 89:607-618.

11. Horton WA: Molecular pathogenesis of achondroplasia. Growth Genet Horm 2006, 22. [http://www.gghjournal.com/volume22/4/featureArticle.cfm]

12. Faivre L, Collod-Beroud G, Loeys BL, Child A, Binquet C, Gautier E, Callewaert B, Arbustini E, Mayer K, Arslan-Kirchner M, Kiotsekoglou A, Comeglio P, Marziliano N, Dietz HC, Halliday D, Beroud C, Bonithon-Kopp C, Claustres M, Muti C, Plauchu H, Robinson PN, Adès LC, Biggin A, Benetts B, Brett M, Holman KJ, De Backer J, Coucke P, Francke U, De Paepe A, et al.: Effect of mutation type and location on clinical outcome in 1,013 probands with Marfan syndrome or related phenotypes and FBN1 mutations: an international study. Am J Hum Genet 2007, 81:454-466.

13. Botstein D, Risch N: Discovering genotypes underlying human phenotypes: past successes for mendelian disease, future approaches for complex disease. Nat Genet 2003, 33(Supp):228-237.

14. Belknap J, Hitzemann R, Crabbe J, Phillips T, Buck K, Williams R: QTL analysis and genomewide mutagenesis in mice: complementary genetic approaches to the dissection of complex traits. Behav Genet 2001, 31:5-15.

15. Mackay TFC, Stone EA, Ayroles JF: The genetics of quantitative traits: challenges and prospects. Nat Rev Genet 2009, 10:565-577.

16. Blake JA, Bult CJ, Kadin JA, Richardson JE, Eppig JT, the Mouse Genome Database Group: The Mouse Genome Database (MGD): premier model 
organism resource for mammalian genomics and genetics. Nucleic Acids Res 2011, 39(suppl 1):D842-D848.

17. Sellier P: Genetically caused retarded growth in animals. Domest Anim Endocrinol 2000, 19:105-119.

18. Reed D, Lawler M, Tordoff M: Reduced body weight is a common effect of gene knockout in mice. BMC Genet 2008, 9:4.

19. Pertea M, Salzberg S: Between a chicken and a grape: estimating the number of human genes. Genome Biol 2010, 11:206.

20. Schwartz MW, Woods SC, Seeley RJ, Barsh GS, Baskin DG, Leibel RL: Is the energy homeostasis system inherently biased toward weight gain? Diabetes 2003, 52:232-238.

21. Jacenko O, LuValle PA, Olsen BR: Spondylometaphyseal dysplasia in mice carrying a dominant negative mutation in a matrix protein specific for cartilage-to-bone transition. Nature 1993, 365:56-61.

22. VanRaden PM, OIson KM, Null DJ, Hutchison JL: Harmful recessive effects on fertility detected by absence of homozygous haplotypes. J Dairy Sci 2011, 94:6153-6161

23. Sutter NB, Bustamante CD, Chase K, Gray MM, Zhao K, Zhu L, Padhukasahasram B, Karlins E, Davis S, Jones PG, Quignon P, Johnson GS, Parker HG, Fretwell N, Mosher DS, Lawler DF, Satyaraj E, Nordborg M, Lark KG, Wayne RK, Ostrander EA: A single IGF1 allele is a major determinant of small size in dogs. Science 2007, 316:112-115.

24. Parker HG, VonHoldt BM, Quignon P, Margulies EH, Shao S, Mosher DS, Spady TC, Elkahloun A, Cargill M, Jones PG, Maslen CL, Acland GM, Sutter NB, Kuroki K, Bustamante CD, Wayne RK, Ostrander EA: An expressed FGF4 retrogene is associated with breed-defining chondrodysplasia in domestic dogs. Science 2009, 325:995-998.

25. Karim L, Takeda H, Lin L, Druet T, Arias JAC, Baurain D, Cambisano N, Davis SR, Farnir F, Grisart B, Harris BL, Keehan MD, Littlejohn MD, Spelman RJ, Georges $\mathrm{M}$, Coppieters W: Variants modulating the expression of a chromosome domain encompassing PLAG1 influence bovine stature. Nat Genet 2011, 43:405-413

26. Boyko AR, Quignon P, Li L, Schoenebeck JJ, Degenhardt JD, Lohmueller KE, Zhao K, Brisbin A, Parker HG, vonHoldt BM, Cargill M, Auton A, Reynolds A, Elkahloun AG, Castelhano M, Mosher DS, Sutter NB, Johnson GS, Novembre J, Hubisz MJ, Siepel A, Wayne RK, Bustamante CD, Ostrander EA: A simple genetic architecture underlies morphological variation in dogs. PLOS Biol 2010, 8:e1000451.

27. Lettre G: Recent progress in the study of the genetics of height. Hum Genet 2011, 129:465-472

28. Aitman TJ, Boone C, Churchill GA, Hengartner MO, Mackay TFC, Stemple DL: The future of model organisms in human disease research. Nat Rev Genet 2011, 12:575-582.

29. Valdar W, Solberg LC, Gauguier D, Burnett S, Klenerman P, Cookson WO, Taylor MS, Rawlins JNP, Mott R, Flint J: Genome-wide genetic association of complex traits in heterogeneous stock mice. Nat Genet 2006, 38:879-887.

30. Bolormaa S, Hayes BJ, Savin K, Hawken R, Barendse W, Arthur PF, Herd RM, Goddard ME: Genome-wide association studies for feedlot and growth traits in cattle. J Anim Sci 2011, 89:1684-1697.

31. Pryce JE, Hayes BJ, Bolormaa S, Goddard ME: Polymorphic regions affecting human height also control stature in cattle. Genetics 2011, 187:981-984.

32. MacArthur JW: Selection for small and large body size in the house mouse. Genetics 1948, 34:194-209.

33. Manolio TA, Collins FS, Cox NJ, Goldstein DB, Hindorff LA, Hunter DJ, McCarthy MI, Ramos EM, Cardon LR, Chakravarti A, Cho JH, Guttmacher AE, Kong A, Kruglyak L, Mardis E, Rotimi CN, Slatkin M, Valle D, Whittemore AS, Boehnke M, Clark AG, Eichler EE, Gibson G, Haines JL, Mackay TF, McCarroll SA, Visscher PM: Finding the missing heritability of complex diseases. Nature 2009, 461:747-753.

34. Yang J, Benyamin B, McEvoy BP, Gordon S, Henders A, Nyholt DR, Madden PA, Heath AC, Martin NG, Montgomery GW, Goddard ME, Visscher PM: Common SNPs explain a large proportion of the heritability for human height. Nat Genet 2010, 42:565-569.

35. Bünger L, Laidlaw A, Bulfield G, Eisen EJ, Medrano JF, Bradford GE, Pirchner F, Renne U, Schlote W, Hill WG: Inbred lines of mice derived from long-term growth selected lines: unique resources for mapping growth genes. Mamm Genome 2001, 12:678-686.

36. Parnell PF, Arthur PF, Barlow R: Direct response to divergent selection for yearling growth rate in Angus cattle. Livest Prod Sci 1997, 49:297-304.

37. Dietz HC, Cutting CR, Pyeritz RE, Maslen CL, Sakai LY, Corson GM, Puffenberger EG, Hamosh A, Nanthakumar EJ, Curristin SM, Stetten G, Meyers DA,
Francomano CA: Marfan syndrome caused by a recurrent de novo missense mutation in the fibrillin gene. Nature 1991, 352:337-339.

38. Pyeritz RE: The Marfan syndrome. Annu Rev Med 2000, 51:481-510.

39. Erkula G, Jones KB, Sponseller PD, Dietz HC, Pyeritz RE: Growth and maturation in Marfan syndrome. Am J Med Genet 2002, 109:100-115.

40. Nollen GJ, Mulder BJM: What is new in the Marfan syndrome? Int J Cardiol 2004, 97(Supplement 1):103-108.

41. Mizuguchi T, Collod-Beroud G, Akiyama T, Abifadel M, Harada N, Morisaki T, Allard D, Varret M, Claustres M, Morisaki H, Ihara M, Kinoshita A, Yoshiura K, Junien C, Kajii T, Jondeau G, Ohta T, Kishino T, Furukawa Y, Nakamura Y, Niikawa N, Boileau C, Matsumoto N: Heterozygous TGFBR2 mutations in Marfan syndrome. Nat Genet 2004, 36:855-860.

42. Loeys B, De Backer J, Van Acker P, Wettinck K, Pals G, Nuytinck L, Coucke P, De Paepe A: Comprehensive molecular screening of the FBN1 gene favors locus homogeneity of classical Marfan syndrome. Hum Mutat 2004, 24:140-146.

43. Mátyás G, Alonso S, Patrignani A, Marti M, Arnold E, Magyar I, Henggeler C, Carrel T, Steinmann B, Berger W: Large genomic fibrillin-1 (FBN1) gene deletions provide evidence for true haploinsufficiency in Marfan syndrome. Hum Genet 2007, 122:23-32.

44. Keane MG, Pyeritz RE: Medical management of Marfan syndrome. Circulation 2008, 117:2802-2813.

45. Judge DP, Biery NJ, Keene DR, Geubtner J, Myers L, Huso DL, Sakai LY, Dietz HC: Evidence for a critical contribution of haploinsufficiency in the complex pathogenesis of Marfan syndrome. J Clin Invest 2004, 114:172-181.

46. Judge DP, Dietz HC: Marfan's syndrome. Lancet 2005, 366:1965-1976.

47. Dietz HC: Marfan Syndrome. In: GeneReviews [Internet]. Edited by Pagon RA, Bird TD, Dolan CR, et al. Seattle: University of Washington; 2011. [http://www. ncbi.nlm.nih.gov/books/NBK1335/]

48. Tatton-Brown K, Cole TRP, Rahman N: Sotos Syndrome. In: GeneReviews [Internet]. Edited by Pagon RA, Bird TD, Dolan CR, et al. Seattle: University of Washington; 2012. [http://www.ncbi.nlm.nih.gov/books/NBK1479/]

49. Tatton-Brown K, Douglas J, Coleman K, Baujat G, Cole TRP, Das S, Horn D, Hughes HE, Temple IK, Faravelli F, Waggoner D, Turkmen S, Cormier-Daire V, Irrthum A, Rahman N; Childhood Overgrowth Collaboration: Genotypephenotype associations in Sotos syndrome: an analysis of 266 undividuals with NSD1 aberrations. Am J Hum Genet 2005, 77:193-204.

50. Kurotaki N, Imaizumi K, Harada N, Masuno M, Kondoh T, Nagai T, Ohashi H, Naritomi K, Tsukahara M, Makita Y, Sugimoto T, Sonoda T, Hasegawa T, Chinen Y, Tomita Ha HA, Kinoshita A, Mizuguchi T, Yoshiura Ki K, Ohta T, Kishino T, Fukushima Y, Niikawa N, Matsumoto N: Haploinsufficiency of NSD1 causes Sotos syndrome. Nat Genet 2002, 30:365-366

51. Beals RK, Hecht F: Congenital contractural arachnodactyly: A heritable disorder of connective tissue. J Bone Joint Surg 1975, 53:987-993.

52. Putnam EA, Zhang H, Ramirez F, Milewicz DM: Fibrillin-2 (FBN2) mutations result in the Marfan-like disorder, congenital contractural arachnodactyly. Nat Genet 1995, 11:456-458.

53. Nishimura A, Sakai H, Ikegawa S, Kitoh H, Haga N, Ishikiriyama S, Nagai T, Takada F, Ohata T, Tanaka F, Kamasaki H, Saitsu H, Mizuguchi T, Matsumoto N: FBN2, FBN1, TGFBR1, and TGFBR2 analyses in congenital contractural arachnodactyly. Am J Med Genet A 2007, 143A:694-698.

54. Godfrey M: Congenital Contractural Arachnodactyly. In: GeneReviews [Internet]. Edited by Pagon RA, Bird TD, Dolan CR, et al. Seattle: University of Washington; 2012. [http://www.ncbi.n/m.nih.gov/books/NBK1386/]

55. Hanson D, Murray PG, O'Sullivan J, Urquhart J, Daly S, Bhaskar SS, Biesecker LG, Skae M, Smith C, Cole T, Kirk J, Chandler K, Kingston H, Donnai D, Clayton $\mathrm{PE}$, Black GC: Exome sequencing identifies CCDC8 mutations in 3-M syndrome, suggesting that CCDC8 contributes in a pathway with CUL7 and OBSL1 to control human growth. Am J Hum Genet 2011, 89:148-153.

56. Huber $C$, Munnich A, Cormier-Daire V: The $3 \mathrm{M}$ syndrome. Best Pract Res Clin Endocrinol Metab 2011, 25:143-151

57. Hanson D, Murray PG, Sud A, Temtamy SA, Aglan M, Superti-Furga A, Holder SE, Urquhart J, Hilton E, Manson FD, Scambler P, Black GC, Clayton PE: The primordial growth disorder 3-M syndrome connects ubiquitination to the cytoskeletal adaptor OBSL1. Am J Hum Genet 2009, 84:801-806.

58. Huber C, Delezoide A-L, Guimiot F, Baumann C, Malan V, Le Merrer M, Da Silva DB, Bonneau D, Chatelain P, Chu C, Clark R, Cox H, Edery P, Edouard T, Fano V, Gibson K, Gillessen-Kaesbach G, Giovannucci-Uzielli ML, Graul-Neumann LM, van Hagen JM, van Hest L, Horovitz D, Melki J, Partsch CJ, Plauchu H, Rajab A, Rossi M, Sillence D, Steichen-Gersdorf E, Stewart H, et al.: A large-scale mutation search reveals genetic heterogeneity in $3 \mathrm{M}$ syndrome. Eur J Hum 
Genet 2008, 17:395-400.

59. Huber C, Dias-Santagata D, Glaser A, O'Sullivan J, Brauner R, Wu K, Xu X, Pearce K, Wang R, Uzielli MLG, Dagoneau N, Chemaitilly W, Superti-Furga A, Dos Santos H, Mégarbané A, Morin G, Gillessen-Kaesbach G, Hennekam R, Van der Burgt I, Black GC, Clayton PE, Read A, Le Merrer M, Scambler PJ, Munnich A, Pan ZQ, Winter R, Cormier-Daire V: Identification of mutations in CUL7 in 3-M syndrome. Nat Genet 2005, 37:1119-1124.

60. Hennekam RCM: Costello syndrome: an overview. Am J Med Genet C 2003, 117C:42-48

61. Gripp KW, Lin AE: Costello Syndrome. In: GeneReviews [Internet]. Edited by Pagon RA, Bird TD, Dolan CR, et al. Seattle: University of Washington; 2012. [http://www.ncbi.nlm.nih.gov/books/NBK1507/]

62. Aoki Y, Niihori T, Kawame H, Kurosawa K, Ohashi H, Tanaka Y, Filocamo M, Kato K, Suzuki Y, Kure S, Matsubara Y: Germline mutations in HRAS protooncogene cause Costello syndrome. Nat Genet 2005, 37:1038-1040.

63. Sol-Church K, Stabley DL, Nicholson L, Gonzalez IL, Gripp KW: Paternal bias in parental origin of HRAS mutations in Costello syndrome. Hum Mutat 2006, 27:736-741.

64. Rousseau F, Bonaventure J, Legeai-Mallet L, Pelet A, Rozet J-M, Maroteaux P, Merrer ML, Munnich A: Mutations in the gene encoding fibroblast growth factor receptor-3 in achondroplasia. Nature 1994, 371:252-254.

65. Aviezer D, Golembo M, Yayon A: Fibroblast growth factor receptor-3 as a therapeutic target for achondroplasia - Genetic short limbed dwarfism. Curr Drug Targets 2003, 4:353-365.

66. Orioli IM, Castilla EE, Barbosa-Neto JG: The birth prevalence rates for the skeletal dysplasias. J Med Genet 1986, 23:328-332.

67. Horton WA, Rotter Jl, Rimoin DL, Scott Cl, Hall JG: Standard growth curves for achondroplasia. J Pediatr 1978, 93:435-438.

68. Shiang R, Thompson LM, Zhu Y-Z, Church DM, Fielder TJ, Bocian M, Winokur ST, Wasmuth JJ: Mutations in the transmembrane domain of FGFR3 cause the most common genetic form of dwarfism, achondroplasia. Cell 1994 78:335-342

69. Oberklaid F, Danks DM, Jensen F, Stace L, Rosshandler S: Achondroplasia and hypochondroplasia. Comments on frequency, mutation rate, and radiological features in skull and spine. J Med Genet 1979, 16:140-146.

70. Heuertz S, Le Merrer M, Zabel B, Wright M, Legeai-Mallet L, Cormier-Daire V, Gibbs $L$, Bonaventure J: Novel FGFR3 mutations creating cysteine residues in the extracellular domain of the receptor cause achondroplasia or severe forms of hypochondroplasia. Eur J Hum Genet 2006, 14:1240-1247.

71. Tiemann-Boege I, Navidi W, Grewal R, Cohn D, Eskenazi B, Wyrobek AJ, Arnheim N: The observed human sperm mutation frequency cannot explain the achondroplasia paternal age effect. Proc Natl Acad Sci U S A 2002, 99:14952-14957.

72. Goriely A, McVean GAT, van Pelt AMM, O'Rourke AW, Wall SA, de Rooij DG, Wilkie AOM: Gain-of-function amino acid substitutions drive positive selection of FGFR2 mutations in human spermatogonia. Proc Natl Acad Sci USA 2005, 102:6051-6056.

73. Borck G, Redon R, Sanlaville D, Rio M, Prieur M, Lyonnet S, Vekemans M, Carter NP, Munnich A, Colleaux L, Cormier-Daire V: NIPBL mutations and genetic heterogeneity in Cornelia de Lange syndrome. J Med Genet 2004, 41:e128.

74. Krantz ID, McCallum J, DeScipio C, Kaur M, Gillis LA, Yaeger D, Jukofsky L, Wasserman N, Bottani A, Morris CA, Nowaczyk MJ, Toriello H, Bamshad MJ, Carey JC, Rappaport E, Kawauchi S, Lander AD, Calof AL, Li HH, Devoto M, Jackson LG: Cornelia de Lange syndrome is caused by mutations in NIPBL, the human homolog of Drosophila melanogaster Nipped-B. Nat Genet 2004, 36:631-635

75. Musio A, Selicorni A, Focarelli ML, Gervasini C, Milani D, Russo S, Vezzoni P, Larizza L: X-linked Cornelia de Lange syndrome owing to SMC1L1 mutations. Nat Genet 2006, 38:528-530.

76. Deardorff MA, Kaur M, Yaeger D, Rampuria A, Korolev S, Pie J, Gil-Rodríguez C, Arnedo M, Loeys B, Kline AD, Wilson M, Lillquist K, Siu V, Ramos FJ, Musio A, Jackson LS, Dorsett D, Krantz ID: Mutations in cohesin complex members SMC3 and SMC1A cause a mild variant of Cornelia de Lange Syndrome with predominant mental retardation. Am J Hum Genet 2007, 80:485-494.

77. Goddard AD, Covello R, Luoh S-M, Clackson T, Attie KM, Gesundheit N, Rundle AC, Wells JA, Carlsson LMS: Mutations of the growth hormone receptor in children with idiopathic short stature. New Eng/ J Med 1995, 333:1093-1098.

78. Laron Z: Laron syndrome (primary growth hormone resistance or insensitivity): The personal experience 1958-2003. J Clin Endocrino/ Metab 2004, 89:1031-1044.

79. Ayling RM, Ross R, Towner P, Laue SV, Finidori J, Moutoussamy S, Buchanan
CR, Clayton PE, Norman MR: A dominant-negative mutation of the growth hormone receptor causes familial short stature. Nat Genet 1997, 16:13-14.

80. Woods KA, Dastot F, Preece MA, Clark AJL, Postel-Vinay MC, Chatelain PG, Ranke MB, Rosenfeld RG, Amselem S, Savage MO: Phenotype:Genotype relationships in growth hormone insensitivity syndrome. J Clin Endocrinol Metab 1997, 82:3529-3535.

81. Le Goff C, Morice-Picard F, Dagoneau N, Wang LW, Perrot C, Crow YJ, Bauer F, Flori E, Prost-Squarcioni C, Krakow D, Ge G, Greenspan DS, Bonnet D, Le Merrer M, Munnich A, Apte SS, Cormier-Daire V: ADAMTSL2 mutations in geleophysic dysplasia demonstrate a role for ADAMTS-like proteins in TGF- $\beta$ bioavailability regulation. Nat Genet 2008, 40:1119-1123.

82. Cormier-Daire V, Le Goff C: Geleophysic Dysplasia. In: GeneReviews [Internet] Edited by Pagon RA, Bird TD, Dolan CR, et al. Seattle: University of Washington; 2009. [http://www.ncbi.nlm.nih.gov/books/NBK11168/]

83. Francomano CA: Hypochondroplasia. In: GeneReviews [Internet]. Edited by Pagon RA, Bird TD, Dolan CR, et al. Seattle: University of Washington; 2005. [http://www.ncbi.nlm.nih.gov/books/NBK1477/]

84. Matsui Y, Kawabata H, Yasui N, Kimura T, Tsumaki N, Ochi T: Genotype phenotype correlation in achondroplasia and hypochondroplasia. J Bone Joint Surg 1998, 80-B:1052-1056.

85. Rousseau F, Bonaventure J, Legeai-Mallet L, Schmidt H, Weissenbach J, Maroteaux P, Munnich A, Le Merrer M: Clinical and genetic heterogeneity of hypochrondroplasia. J Med Genet 1996, 33:749-752.

86. Takeda H, Takami M, Oguni T, Tsuji T, Yoneda K, Sato H, Ihara N, Itoh T, Kata SR, Mishina Y, Womack JE, Moritomo Y, Sugimoto Y, Kunieda T: Positional cloning of the gene LIMBIN responsible for bovine chondrodysplastic dwarfism. Proc Natl Acad Sci U S A 2002, 99:10549-10554

87. OMIA - Online Mendelian Inheritance in Animals [http://omia.angis.org.au/]

88. Galdzicka M, Patnala S, Hirshman MG, Cai JF, Nitowsky H, A Egeland J, Ginns El: A new gene, EVC2, is mutated in Ellis-van Creveld syndrome. Mol Genet Metab 2002, 77:291-295.

89. Koltes JE, Mishra BP, Kumar D, Kataria RS, Totir LR, Fernando RL, Cobbold R, Steffen D, Coppieters W, Georges M, Reecy JM: A nonsense mutation in cGMP-dependent type II protein kinase (PRKG2) causes dwarfism in American Angus cattle. Proc Natl Acad Sci U S A 2009, 106:19250-19255.

90. Pfeifer A, Aszódi A, Seidler U, Ruth P, Hofmann F, Fässler R: Intestinal secretory defects and dwarfism in mice lacking cGMP-dependent protein kinase II. Science 1996, 274:2082-2086.

91. Cavanagh J, Tammen I, Windsor P, Bateman J, Savarirayan R, Nicholas F, Raadsma H: Bulldog dwarfism in Dexter cattle is caused by mutations in ACAN. Mamm Genome 2007, 18:808-814

92. Bell L, Juriloff $\mathrm{M}$, Harris MJ: A new mutation at the $\mathrm{cmd}$ locus in the mouse. J Hered 1986, 77:205-206.

93. Stattin E-L, Wiklund F, Lindblom K, Önnerfjord P, Jonsson B-A, Tegner Y, Sasaki T, Struglics A, Lohmander S, Dahl N, Heinegård D, Aspberg A: A missense mutation in the Aggrecan C-type lectin domain disrupts extracellular matrix interactions and causes dominant familial osteochondritis dissecans. Am J Hum Genet 2010, 86:126-137.

94. Meyer CWE, Korthaus D, Jagla W, Cornali E, Grosse J, Fuchs H, Klingenspor M, Roemheld S, Tschöp M, Heldmaier G, De Angelis MH, Nehls M: A novel missense mutation in the mouse growth hormone gene causes semidominant dwarfism, hyperghrelinemia, and obesity. Endocrinology 2004, 145:2531-2541.

95. McCormack BL, Chase CC Jr, Olson TA, Elsasser TH, Hammond AC, Welsh Jr TH, Jiang H, Randel RD, Okamura CA, Lucy MC: A miniature condition in Brahman cattle is associated with a single nucleotide mutation within the growth hormone gene. Domest Anim Endocrinol 2009, 37:104-111.

96. Mullis PE, Robinson ICAF, Salemi S, Eblé A, Besson A, Vuissoz J-M, Deladoey J, Simon D, Czernichow P, Binder G: Isolated autosomal dominant growth hormone deficiency: An evolving pituitary deficit? A multicenter followup study. J Clin Endocrinol Metab 2005, 90:2089-2096.

97. Feldman B, Poueymirou W, Papaioannou V, DeChiara T, Goldfarb M: Requirement of FGF-4 for postimplantation mouse development. Science 1995, 267:246-249

98. Mariani FV, Ahn CP, Martin GR: Genetic evidence that FGFs have an instructive role in limb proximal-distal patterning. Nature 2008, 453:401-405.

99. Wang P, Branch D, Bali M, Schultz G, Goss P, Jin T: The POU homeodomain protein $\mathrm{OCT3}$ as a potential transcriptional activator for fibroblast growth factor-4 (FGF-4) in human breast cancer cells. Biochem J 2003, 375:1 99-205.

100. Jensen PT, Nielsen DH, Jensen P, Bille N: Hereditary dwarfism in pigs. Nordisk 
Veterinaer Medicin 1984, 36:32-37.

101. Kaman J, Drabek J, Zert Z: Congenital disproportional chondrodysplasia in pigs. Acta Veterinaria Brno 1991, 60:237-251.

102. Nielsen VH, Bendixen C, Arnbjerg J, Sørensen CM, Jensen HE, Shukri NM, Thomsen B: Abnormal growth plate function in pigs carrying a dominant mutation in type X collagen. Mamm Genome 2000, 11:1087-1092.

103. Warman ML, Abbott M, Apte SS, Hefferon T, McIntosh I, Cohn DH, Hecht JT, Olsen BR, Francomano CA: A type X collagen mutation causes Schmid metaphyseal chondrodysplasia. Nat Genet 1993, 5:79-82.

104. Beever JE, Smit MA, Meyers SN, Hadfield TS, Bottema C, Albretsen J, Cockett NE: A single-base change in the tyrosine kinase II domain of ovine FGFR3 causes hereditary chondrodysplasia in sheep. Anim Genet 2006, 37:66-71.

105. Twigg SRF, Healy C, Babbs C, Sharpe JA, Wood WG, Sharpe PT, Morriss-Kay GM, Wilkie AOM: Skeletal analysis of the Fgfr3P244R mouse, a genetic model for the Muenke craniosynostosis syndrome. Dev Dyn 2009, 238:331-342.

106. Online Mendelian Inheritance in Man [http://omim.org/]

107. Weedon MN, Lango H, Lindgren CM, Wallace C, Evans DM, Mangino M, Freathy RM, Perry JR, Stevens S, Hall AS, Samani NJ, Shields B, Prokopenko I, Farrall M, Dominiczak A; Diabetes Genetics Initiative; Wellcome Trust Case Control Consortium, Johnson T, Bergmann S, Beckmann JS, Vollenweider P, Waterworth DM, Mooser V Palmer CN, Morris AD, Ouwehand WH: Cambridge GEM Consortium, Zhao JH, Li S, Loos RJ, Barroso I, Deloukas P, Sandhu MS, et al:: Genome-wide association analysis identifies 20 loci that influence adult height. Nat Genet 2008, 40:575-583.

108. Lanktree MB, Guo Y, Murtaza M, Glessner JT, Bailey SD, Onland-Moret NC, Lettre G, Ongen H, Rajagopalan R, Johnson T, Shen H, Nelson CP, Klopp N Baumert J, Padmanabhan S, Pankratz N, Pankow JS, Shah S, Taylor K, Barnard J, Peters BJ, Maloney CM, Lobmeyer MT, Stanton A, Zafarmand MH, Romaine SP, Mehta A, van Iperen EP, Gong Y, Price TS, et al:: Meta-analysis of dense genecentric association studies reveals common and uncommon variants associated with height. Am J Hum Genet 2011, 88:6-18.

109. N'Diaye A, Chen GK, Palmer CD, Ge B, Tayo B, Mathias RA, Ding J, Nalls MA Adeyemo A, Adoue V, Ambrosone CB, Atwood L, Bandera EV, Becker LC, Berndt SI, Bernstein L, Blot WJ, Boerwinkle E, Britton A, Casey G, Chanock SJ, Demerath E, Deming SL, Diver WR, Fox C, Harris TB, Hernandez DG, Hu JJ, Ingles $S A$, John EM, et al: Identification, replication, and fine-mapping of loci associated with adult height in individuals of african ancestry. PLOS Genet 2011, 7:e1002298.

110. Gudbjartsson DF, Walters GB, Thorleifsson G, Stefansson H, Halldorsson BV Zusmanovich P, Sulem P, Thorlacius S, Gylfason A, Steinberg S, Helgadottir A, Ingason A, Steinthorsdottir V, Olafsdottir EJ, Olafsdottir GH, Jonsson T, BorchJohnsen K, Hansen T, Andersen G, Jorgensen T, Pedersen O, Aben KK, Witjes JA, Swinkels DW, den Heijer M, Franke B, Verbeek AL, Becker DM, Yanek LR, Becker $L C$, et al: Many sequence variants affecting diversity of adult human height. Nat Genet 2008, 40:609-615.

111. Carty CL, Johnson NA, Hutter CM, Reiner AP, Peters U, Tang H, Kooperberg C: Genome-wide association study of body height in African Americans: the Women's Health Initiative SNP Health Association Resource (SHARe). Hum Mol Genet 2012, 21:711-720

112. Okada Y, Kamatani Y, Takahashi A, Matsuda K, Hosono N, Ohmiya H, Daigo Y, Yamamoto K, Kubo M, Nakamura Y, Kamatani N: A genome-wide association study in 19633 Japanese subjects identified LHX3-QSOX2 and IGF1 as adult height loci. Hum Mol Genet 2010, 19:2303-2312.

113. Soranzo N, Rivadeneira F, Chinappen-Horsley U, Malkina I, Richards JB, Hammond N, Stolk L, Nica A, Inouye M, Hofman A, Stephens J, Wheeler E, Arp
P, Gwilliam R, Jhamai PM, Potter S, Chaney A, Ghori MJ, Ravindrarajah R, Ermakov S, Estrada K, Pols HA, Williams FM, McArdle WL, van Meurs JB, Loos RJ, Dermitzakis ET, Ahmadi KR, Hart DJ, Ouwehand WH, et al: Meta-analysis of genome-wide scans for human adult stature identifies novel loci and associations with measures of skeletal frame size. PLoS Genet 2009, 5:e1000445

114. Kim HN, Lee EJ, Jung SC, Lee JY, Chung HW, Kim HL: Genetic variants that affect length/height in infancy/early childhood in Vietnamese-Korean families. J Hum Genet 2010, 55:681-690.

115. Lei SF, Tan L, Liu XG, Wang L, Yan H, Guo YF, Liu YZ, Xiong DH, Li J, Yang TL, Chen XD, Guo Y, Deng FY, Zhang YP, Zhu XZ, Levy S, Papasian CJ, Hamilton JJ, Recker RR, Deng HW: Genome-wide association study identifies two novel loci containing FLNB and SBF2 genes underlying stature variation. Hum Mol Genet 2009, 18:1661-1669.

116. Lettre G, Jackson AU, Gieger C, Schumacher FR, Berndt SI, Sanna S, Eyheramendy S, Voight BF, Butler JL, Guiducci C, Illig T, Hackett R, Heid IM, Jacobs KB, Lyssenko V, Uda M; Diabetes Genetics Initiative; FUSION; KORA; Prostate, Lung Colorectal and Ovarian Cancer Screening Trial; Nurses' Health Study; SardiNIA, Boehnke M, Chanock SJ, Groop LC, Hu FB, Isomaa B, Kraft P, Peltonen L, Salomaa V, Schlessinger D, Hunter DJ, Hayes RB, Abecasis GR, Wichmann HE, Mohlke KL, et al: Identification of ten loci associated with height highlights new biological pathways in human growth. Nat Genet 2008, 40:584-591.

117. Weedon MN, Lettre G, Freathy RM, Lindgren CM, Voight BF, Perry JR, Elliott KS, Hackett R, Guiducci C, Shields B, Zeggini E, Lango H, Lyssenko V, Timpson NJ, Burtt NP, Rayner NW, Saxena R, Ardlie K, Tobias JH, Ness AR, Ring SM, Palmer CN, Morris AD, Peltonen L, Salomaa V; Diabetes Genetics Initiative; Wellcome Trust Case Control Consortium, Davey Smith G, Groop LC, Hattersley AT, McCarthy MI, Hirschhorn JN, Frayling TM: A common variant of HMGA2 is associated with adult and childhood height in the general population. Nat Genet 2007, 39:1245-1250.

118. Collins AL, Lunt PW, Garrett C, Dennis NR: Holoprosencephaly: a family showing dominant inheritance and variable expression. J Med Genet 1993, 30:36-40.

119. Derwinska K, Smyk M, Cooper ML, Bader P, Cheung SW, Stankiewicz P: PTCH1 duplication in a family with microcephaly and mild developmental delay. Eur J Hum Genet 2008, 17:267-271.

120. Cho YS, Go MJ, Kim YJ, Heo JY, Oh JH, Ban H-J, Yoon D, Lee MH, Kim D-J, Park M, Cha SH, Kim JW, Han BG, Min H, Ahn Y, Park MS, Han HR, Jang HY, Cho EY, Lee JE, Cho NH, Shin C, Park T, Park JW, Lee JK, Cardon L, Clarke G, McCarthy MI, Lee JY, Lee JK, et al: A large-scale genome-wide association study of Asian populations uncovers genetic factors influencing eight quantitative traits. Nat Genet 2009, 41:527-534.

121. Hodge J, T.Cuenco K, Huyck K, Somasundaram P, Panhuysen C, Stewart E, Morton C: Uterine leiomyomata and decreased height: a common HMGA2 predisposition allele. Hum Genet 2009, 125:257-263.

122. How Australians Measure Up [http://www.ausstats.abs.gov.au/Ausstats/ subscriber.nsf/Lookup/CA25687100069892CA256889001F4A36/\$Fil e/43590_1995.pdf]

doi:10.1186/gb-2012-13-4-244

Cite this article as: Kemper KE, et al:: Genetic architecture of body size in mammals. Genome Biology 2012, 13:244. 